\title{
PROPORTIONALITY IN THE NEW GERMAN INSURANCE CONTRACT ACT 2008
}

\author{
Helmut Heiss ${ }^{*}$
}

\begin{abstract}
In 2008, the German legislature enacted a completely revised Insurance Contract Act, in which a new rule of proportionality replaced the former all-or-nothing principle for questions of liability. This article outlines the reasons of this shift and the impact of the rule of proportionality on insurers and policyholders. It also addresses the criticisms raised regarding the new system as well as some of the technical problems arising in its application, for example with regard to placement of the burden of proof. This is followed by a short discussion of the rule as it is traditionally applied in Switzerland and as it is adopted in the Principles of European Insurance Contract Law (PEICL).
\end{abstract}

Keywords: all-or-nothing-principle; discharge of the insurer; insurance; PEICL; proportionality rule; proportionate reduction; Swiss Insurance Contract Act

\section{The New German Insurance Contract Act 2008}

The new German Insurance Contract Act (ICA) entered into force on 1 January 2008. Its major aim is to provide policyholders with a level of protection which is in line with modern concepts of consumer law. ${ }^{1}$ This aim was considered to be so fundamental that a limited reform of the old Insurance Contract Act 1908 would not suffice; instead an entirely new codification had to take place. ${ }^{2}$

The codification process was launched on 7 June 2000, when the Federal Ministry of Justice entrusted an expert committee with the drafting of a new Insurance Contract Act. $^{3}$ On 19 April 2004, the expert committee submitted its proposal to the Ministry. ${ }^{4}$ The draft submitted by the expert committee was followed by a draft proposed by the Federal Ministry of Justice on 13 March $2006^{5}$ and the official governmental bill on 20 December $2006 .^{6}$ The bill largely followed the original proposals made by the expert committee, and was enacted with some additional changes ${ }^{7}$ on 23 November $2007 .^{8}$

Dr. iur. (University of Innsbruck), LL.M. (University of Chicago); Professor of Law (University of Zurich); Chairman of the Project Group on a Restatement of European Insurance Contract Law; of counsel, gbf attorneys-at-law, Zurich.

Gesetzentwurfder Bundesregierung, Entwurfeines Gesetzes zur Reform des Versicherungsvertragsrechts vom 20. Dezember 2006, Drucksache 16/3945, at 1 (section A).

2 Kommission zur Reform des Versicherungsvertragsrechts, 'Abschlussbericht der Kommission zur Reform des Versicherungsvertragsrechts vom 19. April 2004', 25 Schriftenreihe der Zeitschrift Versicherungsrecht (2004), at 1.1.2; Gesetzentwurf der Bundesregierung, Entwurf eines Gesetzes zur Reform des Versicherungsvertragsrechts vom 20. Dezember 2006, Drucksache 16/3945, at 47, Begründung (section A.I.).

Bundesministerium der Justiz, Pressemitteilung Nr. 40/00 vom 7. Juni 2000.

4 Kommission zur Reform des Versicherungsvertragsrechts (2004), above n. 2.

5 Referentenentwurf des Bundesministeriums der Justiz zur Reform des Versicherungsvertragsrechts (VVG) vom 13. März 2006.

Gesetzentwurfder Bundesregierung, Entwurfeines Gesetzes zur Reform des Versicherungsvertragsrechts vom 20. Dezember 2006, Drucksache 16/3945.

The final changes were proposed on 28 June 2007 by the Judicial Committee of the German Bundestag; see Beschlussempfehlung und Bericht des Rechtsausschusses (6. Ausschuss) zu dem Gesetzentwurf der Bundesregierung, Entwurf eines Gesetzes zur Reform des Versicherungsvertragsrechts vom 28.06.2007, Drucksache 16/5862.

8 Gesetz zur Reform des Versicherungsvertragsrechts vom 23. November 2007, BGB1. Teil I/2007, Nr. 59 vom 29.11.2007, 2634-2678. 
The statutory materials list 10 major issues at the heart of the law reform, ${ }^{9}$ among them the abolition of the so-called all-or-nothing principle and its replacement by a rule of proportionality. The old all-or-nothing principle discharged insurers of their liability altogether in specific situations. The statutory materials mention, for instance, the discharge of liability in cases of causation of loss (ex $\S 61$ ICA 1908) and in cases of breach of duties (Obliegenheiten), including breach of the duty of disclosure (ex $\S 21$ ICA 1908), of duties relating to an aggravation of risk (ex $\S 25$ ICA 1908), of contractually imposed Obliegenheiten (ex § 6 ICA 1908), etc.

\section{Proportionality in the New German ICA 2008}

\subsection{Discharge of Liability Depends on the Policyholder's Degree of Fault}

\subsubsection{The new system}

The new German ICA 2008 introduces an entirely new principle through which the ability of an insurer to discharge his liability is limited. This is achieved by reducing the insurance money in proportion to the degree of fault apportioned to the policyholder. However, the right of an insurer to reduce the insurance money payable is limited to cases in which the policyholder has acted with gross negligence. ${ }^{10}$ In cases of ordinary negligence, the entire amount of the insurance money will be payable. ${ }^{11}$ In contrast, the insurer will be fully discharged in cases of intentional or fraudulent behaviour by the policyholder. $^{12}$

The statutory materials make clear that this proportionate reduction of the insurance money is, firstly, considered to be fairer than the old all-or-nothing principle. If the insurance money is paid out in its entirety to a policyholder acting with a high degree of ordinary negligence, it seems appropriate to pay out at least a share of the insurance money to a policyholder acting with a low degree of gross negligence. After all, the two situations are factually very similar, and should, thus, not be treated significantly differently. ${ }^{13}$ This would, secondly, make the application of the rule easier. Determinations of fault always require a judgment, and there is, therefore, as a matter of fact, always an element of subjectivity involved. Hence, a judge should not be forced to draw a sharp line between cases of negligence, in which the policyholder will be paid the insurance money without any reduction (all), and cases of gross negligence, in which the policyholder will not receive anything (nothing). Instead, judges should be provided with a flexible system, allowing them to impart justice in accordance with the circumstances of a particular case. ${ }^{14}$

\subsubsection{Criticism of the new system}

The introduction of a system of proportionate reduction of the insurance money payable has led to criticism being raised in German literature. Most of the criticism is based on one or more of three arguments: (1) the new system reduces the deterrent effect of the

\footnotetext{
9 Gesetzentwurfder Bundesregierung, Entwurf eines Gesetzes zur Reform des Versicherungsvertragsrechts vom 20. Dezember 2006, Drucksache 16/3945, at 47-55, Begründung (section A.II.).

$10 \S 26(1) 2, \S 28(2) 2, \S 81(2), \S 82(3) 2$ and $\S 86(2) 3$ ICA 2008.

11 This follows e contrario from the fact that the provisions as listed above $\mathrm{n}$. 10 restrict the right of the insurer to reduce the insurance money to cases of gross negligence.

$12 \S 26(1) 1, \S 28(2) 1, \S 81(1), \S 82(3) 1$ and $\S 86(2) 2$ ICA 2008.

13 Gesetzentwurfder Bundesregierung, Entwurfeines Gesetzes zur Reform des Versicherungsvertragsrechts vom 20. Dezember 2006, Drucksache 16/3945, at 49, Begründung (section A.II.4.); Kommission zur Reform des Versicherungsvertragsrechts (2004) above n. 2, at 1.2.2.10.

14 Gesetzentwurfder Bundesregierung, Entwurfeines Gesetzes zur Reform des Versicherungsvertragsrechts vom 20. Dezember 2006, Drucksache 16/3945, at 49, Begründung (section A.II.4.).
} 
sanctions ${ }^{15}$ (2) the new system privileges careless policyholders to the detriment of careful policyholders $;{ }^{16}(3)$ the new system is too flexible, and consequently creates legal uncertainty, which could lead to an excessively high number of court cases. ${ }^{17}$

The first argument is evidently correct, but appears to oversimplify the matter. First of all, the strict all-or-nothing principle may simply have had an overly deterrent effect. In other words, while a reduction of the insurance money is certainly a more lenient sanction, it may nevertheless be sufficient to deter policyholders from acting with gross negligence. ${ }^{18}$ To take a relatively straightforward example: will a couple who has bought a house using a mortgage more readily attempt to obtain full indemnification by causing fire with gross negligence if they know that they will not lose all, but only part of the insurance money? Obviously, under normal circumstances, nobody wishes to lose a family home, irrespective of how much insurance money will be received. Clearly, a reduction of the insurance money may pose an existential risk to the couple, similar to the risk of a total loss of cover. Thus, it seems that the deterrent effect arising from a proportionate reduction in the amount of insurance money to be paid out would be sufficient in such situations. Moreover, the new system may even increase the deterrent effect. Many authors have argued that, under the old all-or-nothing-principle, judges would often have classified gross negligence as ordinary negligence in order to prevent the policyholder from losing cover altogether.$^{19}$ The incentive to protect policyholders in this way was removed following the introduction of a rule for a proportionate reduction of the insurance money. As a result, the deterrent effect has been increased by the introduction of the rule of proportionality. ${ }^{20}$ Overall, it would appear that the deterrent effect of the new system should, if nothing else, be sufficient.

The second argument is based on the hypothesis that there might be careful policyholders who would never act with gross negligence. Such policyholders would not need to take out insurance covering, at least in part, grossly negligent behaviour. The new German law would, however, force them to insure such behaviour, because it is mandatory in this respect. As a consequence, careful policyholders would subsidise careless policyholders with at least a part of the premium paid. ${ }^{21}$ However, this argument is not well-founded for several reasons. First of all, no one can exclude the possibility of committing a grossly negligent act. Even the old German ICA 1908 contained several provisions demonstrating this point:

- Ex § 152 ICA 1908 provided policyholders with cover for insured events caused by gross negligence in third party liability insurance. Although this provision was not mandatory, and parties could have excluded gross negligence from the cover, the author is unaware of such liability insurance products having been offered or demanded on the German market. If, however, there had been a significant number of policyholders wishing to exclude the possibility of any gross negligence on their part, it would have been a good selling proposition to provide them with cheap liability cover for ordinary negligence only.

\footnotetext{
15 For instance C. Armbrüster, 'Abstufungen der Leistungsfreiheit bei grob fahrlässigem Verhalten des VN', Versicherungsrecht, at 676 (2003).

16 For instance J. Prölss, 'Das versicherungsrechtliche Alles-oder-Nichts-Prinzip in der Reformdiskussion - Allgemeine Überlegungen zum Zwischenbericht der Kommission zur Reform des Versicherungsvertragsrechts vom 30.5.2002', Versicherungsrecht, at 671 (2003).

17 The legislature does not deny that there may be an increase in legal uncertainty, at least for a period of time after the introduction of the principle of proportionality; see Gesetzentwurf der Bundesregierung, Entwurf eines Gesetzes zur Reform des Versicherungsvertragsrechts vom 20. Dezember 2006, Drucksache $16 / 3945$.

18 In detail H. Heiss, 'Kommentar zu $§ 28$ VVG', in H. Baumann, R.M. Beckmann, K. Johannsen and R. Johannsen (eds.), Bruck/Möller, Versicherungsvertragsgesetz, Grosskommentar, vol. 1, Einführung, $\S \S$ $1-32$ (2008), at $\S 28$, para. 187.

19 Zwischenbericht der Kommission zur Reform des Versicherungsvertragsrechts vom 30. Mai 2002, section B.6.

${ }_{20}$ Heiss (2008), above n. 18, at § 28, para. 187.

21 Prölss (2003), above n. 16, at 671 .
} 
- Ex § 67(2) ICA 1908 prevents an insurer from exercising his subrogation rights against the insured's family members, even in cases of grossly negligent behaviour.

- Last but not least, it is a traditional principle of personal insurance law that causation of the insured event by grossly negligent behaviour will not discharge the insurer of his liability (ex $\S \S 169$, 170 ICA 1908 (life assurance); ex § 1781 ICA 1908 (health insurance); ex § 181 ICA 1908 (accident insurance)).

Moreover, the new ICA 2008 provides insurers with remedies, or at least allows insurers to contract for remedies, which will ensure that the social costs of gross negligence will be borne by those policyholders who act carelessly. For instance, the amount of premium charged may be calculated on the basis of the number and size of insured events occurring to a particular policyholder. In this way, careless policyholders causing more insured events will pay an increased premium. ${ }^{22}$ The same happens if insurers decide to terminate the contract following one or several acts committed by the policyholder with gross negligence. ${ }^{23}$ The policyholder will be forced to apply for cover with another insurer, and will have to disclose any cases of gross negligence which have occurred in the past. Consequently, the new insurer will either refuse the application or charge a higher premium. Thus, policyholders are ultimately charged with the costs of their own careless behaviour. ${ }^{24}$

The third argument is clearly correct. The more flexible a legal rule is, the less predictable are the outcomes of individual cases. However, it must be pointed out that flexibility was the main objective of the new rule. Therefore, the legislature consciously decided to pay the price of legal uncertainty in return for equitable solutions. At any rate, leading judges have predicted that a significant body of case law will emerge and provide guidelines, thereby making the reduction of the insurance money more predictable. ${ }^{25}$ Thus, a degree of legal uncertainty, at least for the period of time immediately following the entering into force of the new ICA 2008, is simply the price to be paid for introducing a new equitable regime.

\subsection{Proportionate Reduction as a Sub-system of an Entirely New System of Sanctions}

While the fault-based proportionate reduction of insurance money payable has been the source of most of the discussions accompanying the reform of German insurance contract law, it is only a subsystem or a brick in the wall of a new system of sanctions. This is clear from the mere fact that it only applies in cases of gross negligence, raising the question of what applies in cases of negligence, intention or fraud. In order to fully appreciate the principle of reduction, it must be put into context.

The new German insurance contract law follows, albeit with exceptions, a new and unique system of sanctions. In general, fraudulent behaviour by a policyholder will fully discharge an insurer of his liability, even if an insured event is in no way causally connected to the fraud. ${ }^{26}$ In contrast, intentional behaviour on the part of a policyholder will discharge the insurer only if, and to the extent, that the behaviour has caused the

22 Heiss (2008), above n. 18, at $\S 28$, para. 188.

23 For instance, the right to cancel the contract is granted to the insurer in § 28(1) ICA 2008.

24 Heiss (2008), above n. 18, at § 28, para. 188.

25 Gesetzentwurfder Bundesregierung, Entwurf eines Gesetzes zur Reform des Versicherungsvertragsrechts vom 20. Dezember 2006, Drucksache 16/3945, at 69, Begründung (section B. Zu § 28, Zu Absatz 2).

26 See, e.g., § 28(3) 2 ICA 2008; cf. also Heiss (2008), above n. 18, at § 28, paras. $151 \mathrm{ff}$; in respect of the concept of fraud for the purposes of $\S 28$, cf. Heiss (2008), above n. 18, at $\S 28$, paras. 156 ff.; H.P. Schwintowski, 'Kommentar zu § 28 VVG', in H.P. Schwintowski and C. Brömmelmeyer (eds.), Praxiskommentar zum Versicherungsvertragsrecht (2008), at § 28, paras. 94 ff.; J. Felsch, 'Kommentar $\mathrm{zu} \S 28$ VVG', in W. Rüffer, D. Halbach and P. Schimikowski (eds.), Versicherungsvertragsgesetz, Handkommentar (2009), at § 28, paras. 58 and 76 ff.; M. Wandt, 'Kommentar zu § 28 VVG', in T. Langheid and M. Wandt (eds.), Münchener Kommentar zum Versicherungsvertragsgesetz, vol. 1, Systematische Darstellungen, Erläuterungen zum EGVVG, §§ 1-99VVG (2010), at § 28, paras. $301 \mathrm{ff}$. 
insured event or increased the insurance money payable. ${ }^{27}$ Hence, the old all-or-nothing principle is replaced by a system whereby a discharge from liability depends on the degree of causation. Thus, a policyholder who breaches a contractual duty intentionally may still have a claim to all, or at least part, of the insurance money, depending on the degree of causation. The same applies in cases of gross negligence. Therefore, discharge of an insurer's liability will primarily be limited to the part of the loss caused by grossly negligent conduct. ${ }^{28}$ Within this part, a reduction will be made in proportion to the degree of gross negligence. ${ }^{29}$ The old all-or-nothing principle has consequently been replaced by the cumulative application of two criteria: the degree of causation and the degree of gross negligence. Finally, an insurer will not be discharged from his liability at all where the policyholder acts with negligence. ${ }^{30}$

\subsection{Exemptions from the Rule of Proportionality}

The new system is not without its exceptions. Most importantly, § 21(2) ICA 2008 adheres to the old all-or-nothing principle in cases of non-disclosure or misrepresentation committed with gross negligence. There will be no reduction in the amount of the insurance money payable depending on the degree of gross negligence. At the same time, the discharge of an insurer's liability is not limited to the part of the loss caused by the information which was not disclosed or was misrepresented. Any degree of causation will fully discharge an insurer. If, for instance, the information not disclosed by a policyholder has not caused the loss, but only increased it by $1 \%$, an insurer will nevertheless be fully discharged from his liability. ${ }^{3}$

The harshness of the sanctions applied in cases of a breach of the disclosure duty is, however, alleviated in another way. Where an insurer would have concluded the contract had he known the information which was not disclosed or was misrepresented, albeit in consideration of a higher premium or on other terms, he may only ask for a higher premium or the application of such terms. ${ }^{32}$ In case of gross negligent breach of the disclosure duty, the higher premium or other terms will apply retroactively. ${ }^{33}$

\subsection{Technical Problems of the Rule of Proportionality}

The new principle of proportionate reduction has raised several technical questions regarding its application. It would go far beyond the purposes of this article to deal with these questions in detail. Nevertheless, the problems raised shall be presented, and the solutions favoured so far in court decisions and legal commentary shall be set out.

\subsubsection{Burden of proof}

The first problem addresses the burden of proof concerning the fault of the policyholder. In cases of a breach of contractual duty, it is a general principle of German law that the

\footnotetext{
27 Case law also applies the concept of intent as defined in $\S 276(1)$ of the German Civil Code to insurance law. See Felsch (2009), above n. 26, at $\S 28$, paras. $61 \mathrm{ff}$.; see case law, for example, OLG Köln 15.2.2005 Versicherungsrecht 2005, at 1231; OLG Saarbrücken 12.7.2006 Versicherungsrecht 2007, at 533; BGH 21.4.1993 Versicherungsrecht 1993, at 832; BGH 2.6.1993 Versicherungsrecht 1993, at 960.

28 See, e.g., § 28(3) ICA 2008.

29 See, e.g., \$ 28(2) ICA 2008.

30 See Gesetzentwurf der Bundesregierung, Entwurf eines Gesetzes zur Reform des Versicherungsvertragsrechts vom 20. Dezember 2006, Drucksache 16/3945, at 69, Begründung (section B. $\mathrm{Zu} \S 26, \mathrm{Zu}$ Absatz 1); see also H. Heiss, 'Das Quotensystem im neuen VVG', in C. Brömmelmeyer et al. (eds.), Versicherungswissenschaftliche Studien no. 42 (2012) 191, at 193 et seq.

31 See, for instance, C. Rolfs, 'Kommentar zu § 21 VVG', in H. Baumann, R.M. Beckmann, K. Johannsen and R. Johannsen (eds.), Bruck/Möller, Versicherungsvertragsgesetz, Grosskommentar, vol. 1, Einführung, $\S \S 1$-32 (2008), at $\S 21$, para. 40; see also Heiss (2012), above n. 30, at 193.

32 The first sentence of $\S 19(4)$ ICA 2008.

33 The second sentence of $\S 19(4)$ ICA 2008.
} 
debtor must prove that he acted without fault. ${ }^{34}$ The ICA 2008 follows the same principle and presumes the policyholder to have acted with gross negligence when breaching a contractual duty (except for cases of causation of loss, which are not considered a breach of duty). However, the amount by which the insurance money will be reduced depends not only on the existence (or rather, the presumption) of gross negligence as such, but on its degree. Therefore, there is a debate as to whether the burden of proof for a particular degree of gross negligence lies with the insurer or with the policyholder. ${ }^{35}$ Overall, it seems that most commentators accept the view that a particular degree of gross negligence must be proven by the insurer. ${ }^{36}$

Within this debate, some commentators have proposed that the presumed gross negligence of a policyholder will entitle an insurer to reduce the insurance money by $50 \% .{ }^{37}$ If an insurer wants to increase the reduction, he must prove a degree of gross negligence beyond $50 \%$. In turn, if a policyholder wants to avoid a $50 \%$ reduction, he must prove a degree of negligence below $50 \%$. The vast majority of all commentators reject this proposal, because it would seriously infringe upon the flexibility of the rule, the attainment of which was, after all, the major aim of the legislature. ${ }^{38}$

\subsubsection{Reduction by $0 \%$ or $100 \%$ possible?}

Another debate concerns the question of whether, in appropriate cases, the reduction could amount either to $0 \%$ or even to $100 \%$. The majority of authors believe that this is possible, ${ }^{39}$ and the German Supreme Court has recently confirmed this view. ${ }^{40}$

34 See the second sentence of $\S 280(1)$ of the German Civil Code (BGB).

35 As to the debate with further references, Heiss (2008), above n. 18, at § 28, paras. $217 \mathrm{f}$.

36 Gesetzentwurfder Bundesregierung, Entwurfeines Gesetzes zur Reform des Versicherungsvertragsrechts vom 20. Dezember 2006, Drucksache 16/3945, at 69, Begründung (section B. Zu § 28, Zu Absatz 2); C. Moosbauer, Das quotale Leistungskürzungsrecht des Versicherers bei der grob fahrlässigen Verletzung einer vertraglichen Obliegenheit nach § 28 II S 2 VVG (2011), at 86; J. Prölss, 'Kommentar zu § 28 VVG', in E. Prölss and A. Martin (eds.), Prölss/Martin, Versicherungsvertragsgesetz, Kommentar zu VVG, EGVVG mit Rom I-VO, VVG-InfoV und Vermittlerrecht sowie Kommentierung wichtiger Versicherungsbedingungen (2010), at § 28, para. 138; M. Nugel, 'Quotenbildung bei einer Leistungskürzung nach dem VVG', Monatsschrift für Deutsches Recht, at 1321 (2008); R. Rixecker, 'VVG 2008 - Eine Einführung; II. Obliegenheiten vor dem Versicherungsfall', Zeitschrift für Schadensrecht, at 73 (2007).

37 J. Felsch, 'Neuregelung von Obliegenheiten und Gefahrerhöhung', Recht und Schaden, at 493 (2007); M. Nugel, 'Das neue VVG - Quotenbildung bei der Leistungskürzung wegen grober Fahrlässigkeit', 61 Monatsschrift für Deutsches Recht, at 26 (2007); J. Grote and C. Schneider, 'VVG 2008: Das neue Versicherungsvertragsrecht, Auswirkungen für gewerbliche Versicherungen', Betriebs-Berater, at 2695 (2007); U. Weidner and H. Schuster, 'Quotelung von Entschädigungsleistungen bei grober Fahrlässigkeit des VN in der Sachversicherung nach neuem VVG', Recht und Schaden, at 364 (2007); H. Baumann, 'Quotenregelung contra Alles-oder-Nichts-Prinzip im Versicherungsfall - Überlegungen zur Reform des $\S 61$ VVG', Recht und Schaden, at 9 (2005) de lege ferenda to $\S 81$ (at least $50 \%$ reduction); T. Langheid, 'Die Reform des Versicherungsvertragsgesetzes', Neue Juristische Wochenschrift, at 3669 (2007); critical on this point, Nugel (2008), above n. 36, at 1321; R. Rixecker, 'Quotelung bei Obliegenheitsverletzung: Alles, Nichts oder die Hälfte', 98 Zeitschrift für die gesamte Versicherungswissenschaft, 1, at 6 (2009); D. Looschelders, 'Quotelung bei Obliegenheitsverletzungen: Alles, Nichts oder die Hälfte', 98 Zeitschrift für die gesamte Versicherungswissenschaft, 1, at 28 (2009); of the same opinion, Felsch (2009), above n. 26, at § 28, para. 165; cf. LG Münster 20.8.2009 Versicherungsrecht 2009, at 1615.

38 Gesetzentwurfder Bundesregierung, Entwurf eines Gesetzes zur Reform des Versicherungsvertragsrechts vom 20. Dezember 2006, Drucksache 16/3945, at 69, Begründung (B. Zu § 28, Zu Absatz 2); Heiss (2008), above n. 18, at $\S 28$, para. 190; Moosbauer (2011), above n. 36, at 76 with further references; in detail Heiss (2012), above n. 30, 199 et seq.

39 Heiss (2008), above n. 18, at § 28, para. 195; also LG Dortmund 15.7.2010 Versicherungsrecht 2010, at 1596; compare Wandt (2010), above n. 26, at § 28, para. 240; D. Looschelders, 'Schuldhafte Herbeiführung des Versicherungsfalls nach der VVG-Reform', Versicherungsrecht, at 6 (2008); Felsch (2007), above n. 37 , at 492; Looschelders (2009), above n. 37, at 25 f.; Schwintowski (2008), above n. 26, at § 28, para. 58; Rixecker (2009), above n. 37, at 7; W. Römer, 'Zu ausgewählten Problemen der VVG-Reform nach dem Referentenentwurf vom 13. März 2006 (Teil I)', Versicherungsrecht, at 741 (2006); Weidner and Schuster (2007), above n. 37, at 364; Grote and Schneider (2007), above n. 37, at 2695; of a contrary opinion Prölss (2010), above n. 36, at $\S 28$, para. 136; Nugel (2007), above n. 37, at 27; Schwintowski (2008), above n. 26, at $\S 28$, para. 78 .

40 BGH 22.06.2011, IV ZR 225/10, Beck-Rechtsprechung 2011, at 19286. 


\subsubsection{Multiple reduction}

Yet another question arises where the policyholder has breached more than one duty or where the breach of a duty is accompanied by a causation of the loss. Among the various acts committed with gross negligence, should the one committed with the highest degree of gross negligence be decisive for the overall degree of reducing the insurance money? ${ }^{41}$ Or should the two reductions be added up? ${ }^{42}$ Or should the insurance money, reduced once because of the first act, be further reduced because of the second act? ${ }^{43}$ Or should both acts be taken together, in order to determine an overall reduction in the amount of the insurance money? ${ }^{44}$ It seems that, so far, a majority of commentators take the final view.

\subsubsection{Contractual determination of amount of reduction}

Some commentators have questioned whether parties could set fixed amounts of reduction in their contract. ${ }^{45}$ The answer depends on the degree to which the relevant provisions of the ICA 2008 are mandatory.

$\S 81$ ICA 2008 (causation of loss) is not mandatory. ${ }^{46}$ Therefore, parties are free to derogate from $\S 81$ ICA 2008 by contract. However, if another regime is established by general terms of insurance, such terms might be held to be unfair, and thus void, if they completely eliminate the flexibility of the sanctions. ${ }^{47}$ All the other relevant provisions are mandatory in favour of the policyholder. Consequently, the contract may derogate from these provisions insofar as such derogation is not to the detriment of the policyholder. It is, therefore, the view of this author that the contract may provide for maximum sums by which the insurance money may be reduced, but not, for instance, for a fixed reduction of $50 \%{ }^{48}$

\section{Proportionality: A Short Comparative Note}

\subsection{Origins: ICA 2008 Transplants Art. 14(2) of the Swiss ICA 1908 into German Law}

The concept of reducing insurance money depending on the degree of gross negligence on the part of the policyholder is not an invention created by the German legislature, but rather a legal transplant originating from Swiss insurance contract law. In spite of the fact that the Swiss Insurance Contract Act 1908 not only had the same date of enactment

\footnotetext{
41 Nugel (2007), above n. 37, at 31; Felsch (2007), above n. 37, at 497; critical C.D. Günther and S. Spielmann, 'Vollständige und teilweise Leistungsfreiheit nach dem VVG 2008 am Beispiel der Sachversicherung (Teil 2)', Recht und Schaden, at 185 (2008); dissenting Grote and Schneider (2007), above n. 37, at 2695 f.; Prölss (2010), above n. 36, at $\S 28$, para. 132; Felsch (2009), above n. 26, at $\S 28$, paras. $189 \mathrm{ff}$.

42 Felsch (2007), above n. 37, at 496 f.; Günther and Spielmann (2008), above n. 41, at 185; Nugel (2007), above n. 37, at 31; Heiss (2008), above n. 18, at § 28, para. 199; Prölss (2010), above n. 36, at $\S 28$, para 133; Felsch (2009), above n. 26, at $\$ 28$, para. 187.

43 Günther and Spielmann (2008), above n. 41, at 186; Nugel (2007), above n. 37, at 31; Nugel (2008), above n. 36, at 1325; cautiously approving Prölss (2010), above n. 36, at § 28, para. 134.

44 Felsch (2007), above n. 37, at 497; R. Hess and M. Burmann, 'Die Quote bei grob fahrlässiger Obliegenheitsverletzung', Neue Zeitschrift für Verkehrsrecht, at 10 (2009); Wandt (2010), above n. 26, at $\S 28$, paras. 248 f.; P. Pohlmann, 'Kommentar zu $§ 28$ VVG', in D. Looschelders and P. Pohlmann (eds.), VVG-Kommentar (2010), at § 28, para. 123; Rixecker (2009), above n. 37, at 9; Looschelders (2009), n. 37, at 30; dissenting Günther and Spielmann (2008), above n. 41, at 185; Prölss (2010), above n. 36, at $\S 28$, para. 132.

45 Heiss (2008), above n. 18, at $\S 28$, para. 198; Heiss (2012), above n. 30, at 205; Wandt (2010), above n. 26 , at $\S 28$, para. 256

46 See $\$ 87$ ICA 2008

47 See $\S 307(1)$ together with (2)(1) of the German Civil Code.

48 Heiss (2008), above n. 18, at $\S 28$, para. 203.
} 
as the old German ICA 1908, but also included the all-or-nothing principle, ${ }^{49}$ Art. 14(2) of the Swiss ICA 1908 deviated from this principle and established a principle of proportionate reduction in cases of loss caused by grossly negligent conduct. However, proportionality does not apply in cases of breach of (contractual) duties, such as the precontractual duty of disclosure (Arts. 4 and 5 of the Swiss ICA 1908), the duty to avoid and/or disclose aggravations of risk (Arts. 28 and 30 of the Swiss ICA 1908), the duty to take precautionary measures (Art. 29 of the Swiss ICA 1908), the duty to notify the loss (Art. 38 of the Swiss ICA 1908), etc.

Art. 14(2) of the Swiss ICA 1908 was used as a model for the new German ICA 2008. The German legislature did not, however, restrict the principle of proportionate reduction to cases of causation of loss, but extended its scope of application to cases of breach of (contractual) duty, despite the two being different in nature. Most importantly, causation of loss is not considered to be a breach of a duty, but the subject of a statutory exemption clause ( $\S 81$ of the German ICA 2008), discharging the insurer of his liability. Nevertheless, the legislature thought that policyholder protection justified an application of the principle of proportionality, even in cases of breach of duty.

It would appear that the approach taken by the German legislature will be followed by the Swiss legislature. The most recent governmental bill for an entirely new Swiss Insurance Contract Act (Swiss Draft ICA) proposed on 7 September $2011^{50}$ follows the German model, and also extends the principle of proportionality to cases of breach of (contractual) duty. ${ }^{51}$ The Swiss legislature even attempts to improve upon the new German ICA 2008, as it proposes to incorporate cases of grossly negligent breach of the pre-contractual duty of disclosure into the system of proportionality. ${ }^{52}$

It might be assumed that the new German ICA 2008 and the future Swiss ICA will in fact be very similar, at least as far as the proportionate reduction of insurance money is concerned. Indeed, this might be true if one looks at the black letter law only. However, there are important differences in the living insurance laws of Germany and Switzerland. Some are due to differences in the black letter law, which appear to be of minor importance at first sight, but turn out to have a strong practical impact. Others are due to a different culture in dealing with proportionality.

An apparently minor difference in black letter law concerns the burden of proof for causation, which will have a tremendous effect on the living laws of both countries. ${ }^{53}$ Under the German ICA 2008, the burden of proving lack of causation lies with a policyholder in cases of breach of (contractual) duty. The burden of proof lies with an insurer only in cases of causation of loss. In contrast, the burden of proving a causal link between the behaviour of a policyholder and the insured event or the degree of loss lies with an insurer in all cases under the Swiss Draft ICA. Given the fact that a causal link, or an absence thereof, is very hard to prove in cases of breach of contractual duty, the different attributions of the burden of proof is expected to produce widely differing results in Germany and Switzerland.

The cultural aspect concerns the attitude of courts towards reducing insurance money. Recent studies have clearly shown that German courts readily reduce insurance money by $50 \%$ or more and, in cases of driving while intoxicated, even by $100 \%$ if a blood alcohol content of $0.1 \%$ or more is reached. ${ }^{54}$ In contrast, reductions in the amount of the insurance money by Swiss courts come to no more than $10 \%-50 \%$ in the vast

\footnotetext{
49 For instance, Arts. 6 and 8 of the Swiss ICA 1908.

50 Bundesgesetz über den Versicherungsvertrag (Versicherungsvertragsgesetz, VVG) (Entwurf), SR 221.229.1 (available online at <http://www.admin.ch/ch/d/ff/2011/7819.pdf $>$ ).

51 See Arts. 19(1) and 41(6) of the Swiss Draft ICA.

52 See Art. 19(1) of the Swiss Draft ICA.

53 See in detail U. Mönnich, "Vom "Alles-oder-Nichts-Prinzip" zur Quotelung der Versicherungsleistung - Rechtsvergleichende Überlegungen zur Reform des Versicherungsvertragsrechts in der Schweiz und in Deutschland', in A.K. Schnyder (ed.), Totalrevision des VVG (2012 in print).

54 See in detail id.
} 
majority of all cases ${ }^{55}$ Moreover, academic studies indicate that insurers usually reduce the insurance money even less than the courts. ${ }^{56}$ Proportionate reduction is, therefore, a very different concept in German and Swiss practice.

\subsection{Possible Future: Proportionality in European Insurance Contract Law?}

\subsubsection{Preliminary remark: Plans for a future European Insurance Contract Law}

Strong efforts are currently being made towards the creation of a European insurance contract law. Academics published the first volume of Principles of European Insurance Contract Law (PEICL) in 2009, ${ }^{57}$ which will be followed by a second, final volume in 2013 or early 2014. The PEICL have been drafted as an optional instrument of European insurance contract law, allowing parties to opt out of national (insurance) law by opting for the application of the PEICL. Due to the mainly mandatory character of the rules on international insurance contract law (Art. 7 Rome I) ${ }^{58}$ and national insurance contract law, ${ }^{59}$ this option does not exist at present; it requires an EU regulation on the matter.

EU institutions have repeatedly expressed their wish or intent to use the PEICL as a draft for a regulation to establish an optional instrument of European insurance contract law. The following documents deserve special mention:

- Opinion of the European Economic and Social Committee on 'The European Insurance Contract'; ${ }^{60}$

- Opinion of the European Economic and Social Committee on 'The 28th regime - an alternative allowing less law making at Community level'; ${ }^{\prime}$

- Green Paper from the Commission of 1 July 2010 on policy options for progress towards a European Contract Law for consumers and businesses; ${ }^{62}$

- European Parliament Resolution of 8 June 2011 on policy options for progress towards a European Contract Law for consumers and businesses; ${ }^{63}$

- Press Release 'EU Justice Commissioner Viviane Reding meets with leaders of Europe's insurance industry' (21 September 2011). ${ }^{64}$

\subsubsection{Proportionality in the PEICL}

The PEICL deal with causation of loss (Article 9:101 PEICL), precautionary measures (Articles 4:101 f. PEICL), pre-contractual duty of disclosure (Articles 2:101 f. PEICL), aggravation of risk (Articles 4:201 f. PEICL), as well as notification of the insured event (Article 6:101 PEICL) and claims cooperation (Article 6:102 PEICL). Each of these provisions also governs a potential discharge of an insurer's liability or a reduction in the amount of the insurance money. The approach taken varies:

If the loss is caused by the policyholder or the insured, an insurer shall be discharged of his obligation to pay insurance money only if the policyholder or the insured has

\footnotetext{
55 See, for instance, M.C. Feifel, Die Quotelung bei Obliegenheitsverletzungen nach \& 28 VVG 2008 (2011), at $135 \mathrm{ff}$.

56 With further references to German and Swiss court cases and literature, Mönnich, above n. 53.

57 J. Basedow, J. Birds, M.A. Clarke, H. Cousy and H. Heiss (eds.), Principles of European Insurance Contract Law (PEICL) (2009).

${ }_{58}$ Regulation (EC) No 593/2008 of the European Parliament and of the Council of 17 June 2008 on the law applicable to contractual obligations (Rome I) [2008] OJ L177/6.

59 See H. Heiss, 'Introduction', in Basedow et al., above n. 57, at $15 \mathrm{f}$.

60 [2005] OJ C157/1.

61 [2011] OJ C21/26.

$62 \operatorname{COM}(2010) 348$ final.

63 2011/2013(INI).

$64 \mathrm{MEMO} / 11 / 624$.
} 
acted 'with intent to cause the loss or recklessly and with knowledge that the loss would probably result'. ${ }^{65}$ Negligent causation will not discharge the insurer at all. However, an insurer is allowed to introduce a clause into the policy 'providing for a reduction of the insurance money according to the degree of fault' on the part of the policyholder or insured ${ }^{66}$ If insurers were in fact to use this option, as might be expected, the living law of the PEICL would follow the principle of proportionality in a similar manner to $\S 81$ German ICA 2008 and Art. 14(2) of the Swiss ICA/Art. 41(2) of the Swiss Draft ICA. The same approach is used by the PEICL in cases of failure to avert or mitigate the loss ${ }^{67}$ or to take precautionary measures. ${ }^{68}$

There is, however, an alternative approach taken by the PEICL in cases of breach of the duty to disclose and of aggravation of loss. The insurer will only be (totally or partially) discharged in cases of aggravation of risk in which the policyholder is, or ought to be, aware of the aggravation. ${ }^{69}$ In addition, the insured event must have been caused by the aggravated risk..$^{70}$ If these requirements are fulfilled, the discharge of the insurer will not depend upon the degree of fault on the part of the policyholder. Rather, the insurer will be entirely discharged if he would not have insured the aggravated risk at all. ${ }^{71}$ If, however, the insurer would have insured the aggravated risk in return for a higher premium or on other terms, a discharge would depend on the ratio between the premium paid and the premium hypothetically owed, had the aggravation been covered in the contract or on the other terms which would have been agreed upon. ${ }^{72}$ An analogous approach is used if the pre-contractual disclosure duty is breached by the policyholder. ${ }^{73}$

Yet another approach is used in cases where the policyholder has not notified the insurer of the insured event ${ }^{74}$ or has not cooperated with the investigation of the insured event. ${ }^{75}$ In both cases, the insurer will be allowed to reduce the insurance money to the extent 'that the insurer proves that it has been prejudiced' by the delayed notification or breach of the duty to cooperate. ${ }^{76}$

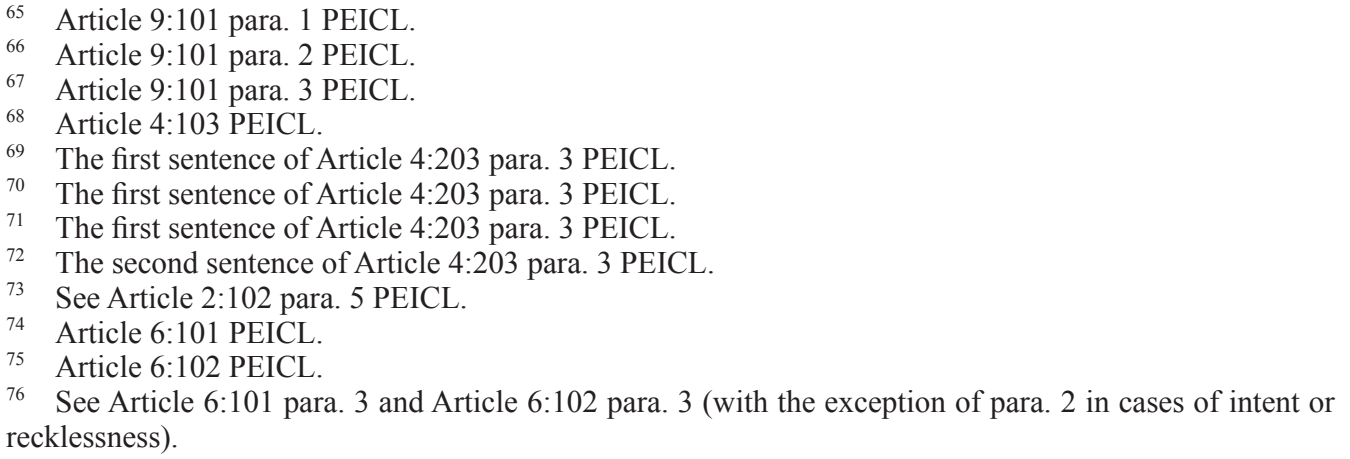

